\title{
Individual and Collective Rights in Work Relations: Reflections on the Current State of Labor Law and Its Prospects
}

\author{
Charles Fried $\dagger$
}

In the last decade radical-left legal scholars have mounted an historical, social, and analytical attack on the established system of American labor law. ${ }^{1}$ The very force of their attack and its concerted nature would tempt one to view with affection a legal and social structure that otherwise seems singularly unloveable. After all, as Bok and Dunlop showed more than a decade ago, few American institutions are held in lower esteem by the general public than labor unions, few public actors in lower regard than labor leaders. ${ }^{2}$ Nor have the intervening years softened this judgment. On the contrary, there is a widespread feeling that unionswhether alone or in concert with management in such industries as automobiles and steel-have made a major contribution to the country's industrial malaise. ${ }^{3}$

Yet on this occasion, at least, one should resist the temptation to rally automatically around the New Deal rhetoric that has come down to us with the Wagner Act system." The fact of the matter is

† Carter Professor of General Jurisprudence, Harvard Law School. I have learned from detailed comments by Richard Epstein and Karl Klare and from discussion with Bruce Ackerman, Jonathan Bennett, Anthony Kronman, and Judith Thomson. Especial thanks are due to my colleagues David Rosenberg and Paul Weiler for their indulgence in tutoring a neophyte.

I See, e.g., James B. Amleson, Valuzs and Assumptions in American labor Law (1983); Kennedy, Critical Labor Law Theory: A Comment, 4 Indus. REx. L.J. 503 (1981); Klare, Labor Law as Ideology: Toward a New Historiography of Collective Bargaining Law, 4 InDUs. REL. L.J. 450 (1981) [hereinafter cited as Klare, Labor Law]; Klare, Judicial Deradicalization of the Wagner Act and the Origins of Modern Legal Consciousness, 19371941, 62 Minn. L. REv. 265 (1978) [hereinafter cited as Klare, Deradicalization]; Lynd, Government Without Rights: The Labor Law Vision of Archibald Cox, 4 INDus. REL. L.J. 483 (1981); Lynd, Investment Decisions and the Quid Pro Quo Myth, 29 CASE W. Rrs. L. Rzv. 397 (1979) [hereinafter cited as Lynd, Investment Decisions]; Stone, The Post-War Paradigm in American Labor Law, 90 YaLE L.J. 1509 (1981); Unger, The Critical Legal Studies Movement, 96 HARv. L. REv. 561, 629-32 (1983).

D. BoK \& J. Dunlop, Labor and the AmrRican Communtty 14-19 (1970).

- See, e.g., Kauss, The Trouble With Unions, HARPER's, June 1983, at 23. But see Kuttner, Can Labor Lead?, NEw REPuBur, March 12, 1984, at 19.

- The statutory framework of the system is contained in the National Labor Relations Act of 1935, as amended, 29 U.S.C. $\$ \S 151-169$ (1982) [hereinafter cited without cross-refer- 
that the radical-left critique of the Wagner Act system has legitimated (a favorite word in the radical-left lexicon) an inquiry into the value and justice-indeed the necessity-of the basic presuppositions of that system. For two generations, to question the assumptions of that system would have been the equivalent for a legal scholar of proclaiming himself a Flat Earther. The radical-left critique has rendered the signal service of opening those assumptions to question. And though the usual orthodoxy of legal academia has a distinctly "pas d'ennemi à la gauche" bias and thus is particularly ready to tolerate a critique from the left, once the issue was raised it became inevitable that we would hear from all quarters.

Karl Klare has argued that the present insipid state of labor militancy in America and the half-hearted concession of even slight status to working people are the result of the consistent undermining by the judiciary of what might have been, and was meant to be, a radical transformation of American capitalism, vesting significant proprietary rights in the working class. ${ }^{.}$According to this view, the Wagner Act might have been the occasion for, and perhaps was intended to be, a major expropriation, a revolution, a reordering of authority over industry akin to the freeing of the serfs or to the redistribution of land in a peasant economy. Though the revolution was not quite meant to lead to the sole ownership of the means of production by the workers, at least a regime of co-ownership with the capitalists was intended. Whether this radical purpose constituted an expropriation in favor of individual workers or instead what might be called a collective expropriation - that is, in favor of unions-is not so clear. To the extent that the distinction is made, Klare assumes the latter alternative. ${ }^{6}$

Klare argues that a number of decisions have been crucial to the process of judicial emasculation of the Wagner Act system. A major culprit is the Borg-Warner decision, ${ }^{7}$ which established the

ence as NLRA].

- See Klare, Deradicalization, supra note 1, at 292-93.

- Id. at 289-90.

7 NLRB v. Wooster Div. of Borg-Warner Corp., 356 U.S. 342 (1958). Borg-Warner emphasized the distinction between subjects of mandatory bargaining, such as wages, hours, and working conditions, and subjects of optional bargaining. The case involved an employer who bargained in good faith over wages and hours but refused to accept the bargain unless clauses relating to internal union governance were also included in the agreement. The employer was found in substance to have refused to bargain as to the wages and hours, since it was illusory to find that a bargain had been struck over the mandatory subjects while the agreement as a whole was held hostage to provisions relating to nonmandatory subjects. 356 U.S. at 348-50. This apparently pro-union position was carried to its allegedly pernicious 
principle that a whole range of issues-especially issues regarding investment, production, site location, and the like-were not things about which management was required to bargain under section 8(d) of the Act, ${ }^{8}$ although they surely have a powerful impact on workers' employment prospects and conditions. ${ }^{\ominus}$ Never mind that the general testimony of experienced persons holds that any labor union with the determination and the strength to do so can easily impose its will with respect to such "nonmandatory" subjects, while a weak union or a union in a weak economy can hardly do so even with respect to a mandatory subject. ${ }^{10}$

Similarly, the Mackay Radio decision, ${ }^{11}$ which allowed employers to find permanent replacements for striking workers, has been attacked, first, as undermining the right to strike, and second, more radically, as reasserting, like the Borg-Warner decision, the proprietary rights of management that, it is said, were expropriated to the unions by the Wagner Act. ${ }^{12}$ In a similar vein, Klare condemns the Fansteel decision, ${ }^{13}$ which allowed the discharge of sit-down strikers, as a derogation of the Wagner Act's protection of the workers' right to take concerted action.

Katherine Stone has argued that the prevalence of arbitration, far from offering neutral resolution of labor disputes, functions inevitably to the benefit of management, since the role of arbitration is to preserve order in the plant, while the bargaining and organizing power of unions lies in the ability to create disorder through bracing recourse to periodic strikes and disruptions. ${ }^{14}$ She does not emphasize, of course, that the substitution of arbitration for strikes

conclusion in Justice Stewart's concurrence in Fibreboard Paper Prods. v. NLRB, 379 U.S. 203, 223 (1964) (employer has no duty to engage in collective bargaining over matters "which lie at the core of entrepreneurial control," such as the decision to invest in laborsaving machinery). A recent decision with some bite is First Nat'l Maintenance Corp. v. NLRB, 452 U.S. 666, 678-79 (1981) ("Management must be free from the constraints of the bargaining process to the extent essential for the running of a profitable business.").

8 NLRA \& 8(d), 29 U.S.C. § 158(d) (1982).

- See Lynd, Investment Decisions, supra note 1, at 410.

10 See, e.g., Harry Wellington, Labor and the Legal Process 63-90 (1968). Indeed, even in First Nat'l Maintenance Corp. v. NLRB, 452 U.S. 666 (1981), though the Court held that the employer need not bargain about the nonrenewal of an unprofitable contract to provide service to a particular client, the force of the holding was considerably blunted by the Court's concession that the employer was obliged to bargain about the effects of the resulting layoffs. Id. at 677 n.15.

11 NLRB v. Mackay Radio \& Tel. Co., 304 U.S. 333 (1938).

12 See J. AtLeson, supra note 1, at 19-34; Klare, Deradicalization, supra note 1, at 30103.

${ }^{13}$ Klare, Deradicalization, supra note 1, at 318-25 (discussing NLRB v. Fansteel Metallurgical Corp., 306 U.S. 240 (1939)).

14 Stone, supra note 1, at 1565. 
only occurs pursuant to terms in a collective-bargaining agreement to which the union itself has consented. The judicial reintroduction of the labor injunction ${ }^{15}$ has a particularly strong stink in the nostrils of both Stone and Klare. ${ }^{18}$ They are also inclined to see restrictions on union solidarity, such as the prohibition of secondary boycotts and limitations on unions' rights to discipline their members, ${ }^{17}$ as further evidence of the defanging of the Wagner Act, though in both instances the dentist was surely Congress (through the Taft-Hartley Act ${ }^{18}$ ) with the courts standing by only as technicians.

Somewhat at variance with the "emasculation" critique is James Atleson's line that courts have, wherever possible, interpreted the Wagner Act itself to carry forward preceding assumptions, embedded in the common law, about the nature of the employment relationship, the workers' duty of loyalty to their employer, and the like. ${ }^{19}$ In this way, Atleson argues, the courts have undermined the reordering of proprietary rights intended by the draftsmen of the Act.

Finally, and inevitably, a standard Critical Legal Studies trope, that of the incoherence of liberal thought, has been turned on labor law to show how its doctrines-particularly the doctrine of the duty to bargain in good faith-suffer from the typical internal self-contradictions of liberal thought: there is an attempt at one and the same time to interfere and not to interfere, to transfer a measure of power to employees, while withholding any substantial title to enjoy that power. The doctrine is seen as a typical example of the liberal predilection for avoiding questions of substance by the creation of procedures. ${ }^{20}$

As I have indicated, the radical-left critique has authorized a reconsideration of the foundations of the Wagner Act system. Richard Epstein's libertarian critique takes as its point of depar-

1s See Boy's Mkts., Inc. v. Retail Clerks Union, Local 770, 398 U.S. 235 (1970).

16 See Klare, Labor Law, supra note 1, at 454 \& n.14; Stone, supra note 1, at 1542-44.

17 For a discussion of this latter issue, including recommended standards for balancing the union's right to discipline members with the individual's right to resign, see generally Gould (not a radical legal scholar!), Solidarity Forever-Or Hardly Ever: Union Discipline, Taft-Hartley, and the Right of Union Members to Resign, 66 CoRnew L. Rev. 74 (1980). In Machinists Local 1327 v. NLRB, 725 F.2d 1212 (9th Cir.), denying enforcement to 263 N.L.R.B. 984 (1984), the Ninth Circuit held, contrary to the Board's ruling, that a union lawfully may discipline members who resign after a strike begins.

1. Labor Management Relations (Taft-Hartley) Act, Pub. L. No. 80-101, 61 Stat. 136 (codified in relevant part in scattered sections of 29 U.S.C.).

10 See J. Atusson, supra note 1, at 1-10.

so See Unger, supra note 1 , at $630-31$. 
ture the principle that the sole presumptively legitimate function of the law is to protect individuals from fraud and violence and that the law should enforce all contracts untainted by either. ${ }^{21} \mathrm{He}$ therefore finds a number of important derogations from sound principle in the Wagner Act system. These are, indeed, the very expropriatory aspects of that system celebrated by the left-radicals, the thwarting of which they lament.

Thus, Epstein objects to the prohibitions on employer discrimination $^{22}$ and on interference with employee self-organization. ${ }^{23}$ If the plant belongs to the employer, why can he not employ whomever he wishes, on such conditions as he chooses (and in which he can get someone else to concur), and why should the law not enforce such conditions against those who would organize on his property to institute a regime he does not like? To prohibit employment contracts excluding or limiting union membership-socalled "yellow dog" contracts-according to this view is to interfere with two freely contracting parties who, by hypothesis, are willing to deal on another basis. ${ }^{24}$ Similarly, Epstein objects to the prohibition on employer domination of labor organizations, company unions and the like, on grounds of both freedom of contract and efficiency. ${ }^{26}$

As I have written on another occasion in reference to other of his writings, ${ }^{26}$ Epstein's analysis is vulnerable at its central premise: the definition of the property rights involved. Only by assuming that the preexisting common law system of property rights had some natural, preconventional status can the expropriationary thrust of the Wagner Act (to the extent that there is one) be criticized. If, however, property rights are-as thinkers from Kant ${ }^{27}$ to Nozick $^{28}$ have held-essentially conventional, then Epstein runs up against the problem of showing why the Wagner Act system does not represent simply a redefinition by society of what have always been social conventions in any event. What Epstein needs, but in

21 See Epstein, A Common Law for Labor Relations: A Critique of the New Deal Labor Legislation, 92 YaLE L.J. 1357, 1357-63 (1983).

${ }^{22}$ Id. at 1392-94 (discussing NLRA \& 8(a)(3), 29 U.S.C. § 158(a)(3) (1982)).

${ }^{23}$ Epstein, supra note 21, at 1387-91 (discussing NLRA $\$ 8(\mathrm{a})(1), 29$ U.S.C. $\$ 158(\mathrm{a})(1)$ (1982)).

24 Epstein, supra note 21, at 1370-75, 1382-85.

${ }^{25}$ Id. at 1391-92 (discussing NLRA § 8(a)(2), 29 U.S.C. § 158(a)(2) (1982)).

${ }^{28}$ See Fried, Is Liberty Possible?, in 3 The Tanner Lectures in Human Values 91, 119-29 (1982) (discussing Epstein's theory of tort law).

${ }^{27}$ See Immanuel Kant, The Metaphysical Elements of Justice 255-56 (Prussian Academy ed. standard pagination) (1st ed. Königsberg 1797).

${ }^{28}$ See Robert Nozick, ANarchy, State, ANd Utopia 174-78 (1974). 
my view does not provide, ${ }^{29}$ is an account of the relevant property rights that shows why they are preconventional and why they should be protected from government tampering.

Standing between these two attacks is a vast, ponderous, powerful, but threadbare middle view. Built up of formulas repeated until they have become platitudes, this view proclaims such values as equalizing the bargaining power of labor and management, forming a partnership of labor and management, instituting industrial democracy, and, at every turn, preserving industrial peace. ${ }^{30}$ While the percentage of workers represented by unions subject to the Wagner Act system declines-it is now down to about eighteen percent from a high of thirty-five percent ${ }^{31}$ - traditional labor lawyers continue lovingly to elaborate the arcane doctrines relating to such intricacies as secondary boycotts, informational picketing, and mandatory subjects of bargaining. One might truly describe the field as an instance of more and more about less and less.

My colleague Paul Weiler, writing from a perspective that was originally Canadian, ${ }^{32}$ is refreshingly direct about these trends. Noting the decline in union membership and the increasing number of representational elections that go against unions, he looks for reparable defects in the structure of our labor laws. ${ }^{\text {s3 }}$ An example is the ease with which management can create delays in $\mathrm{Na}-$

20 Epstein's own view is that he has provided such an account. See Epstein, Possession as the Root of Title, 13 GA. L. Rav. 1221, 1238-43 (1979); Epstein, Nuisance Law: Corrective Justice and Its Utilitarian Constraints, 8 J. LBgal Stud. 49, 74-75 (1979); Epstein, A Theory of Strict Liability, 2 J. LBgAL STUD. 151, 200-02 (1973).

${ }^{30}$ See, e.g., Emporium Capwell Co. v. Western Addition Community Org., 420 U.S. 50, 62 (1975) (goal of national labor policy is to minimize "industrial strife" by encouraging collective bargaining); United Steelworkers v. Warrior \& Gulf Navigation Co., 363 U.S. 574, 580 (1960) (collective bargaining is an effort "to erect a system of industrial self-government"). These platitudes were subject to astringent criticism in American Ship Building Co. v. NLRB, 380 U.S. 300, 316-17 (1965) (NLRB has no authority to balance competing interests of labor and management or to base its rulings upon its own assessment of their relative bargaining power).

s1 In 1946, the unionized sector of the nonagricultural work force reached a high of about 35\%. N. Chamberdatn, D. Culleen \& D. Lewin, Thi Labor Sector 124 (1980). By 1980, this figure had fallen to 25.2\%. Statistical ABstract of the Untred States 440 (1984). It is now estimated that the unionized sector of the total work force has reached an all-time low of $17.9 \%$. BNA Survey on Union Membership Statistics, 117 LAB. REL. RBP. (BNA) 81, 81 (1984).

22 See Paul Weiler, Labor Arbitration and Industrial Change (1969).

${ }^{23}$ See Weiler, New Balance at the Bargaining Table: Freedom of Contract and the Prospects for Union Representation, HARv. L. Rkv. (forthcoming) (dealing with first contract negotiations) [hereinafter cited as Weiler, Freedom of Contract]; Weiler, Promises to Keep: Securing Workers' Rights to Self-Organization Under the NLRA, 96 HaRv. L. Rsv. 1769 (1983) [hereinafter cited as Weiler, Promises to Keep]. 
tional Labor Relations Board enforcement proceedings ${ }^{34}$ and obstruct union representation elections. ${ }^{35}$ Weiler's prescription is more incremental than radical. He calls for union certification without protracted election campaigns (perhaps even on the basis of authorization cards signed by employees during the union's organizing drive, without the formalities of a supervised election and secret ballot); ${ }^{36}$ recourse in cases of deadlock to compulsory arbitration of first union contracts; ${ }^{37}$ reversal of the Mackay Radio rule, which allows automatic hiring of permanent replacements for strikers; $;^{38}$ loosened rules against secondary boycotts; $; 9$ and a firmer union hold on workers, attained by increasing their power to discipline members. ${ }^{40}$

The energizing premise of these adjustments is that unionization is the natural condition of industrial men and women, and to the extent that this natural condition is not only not increasing but is decreasing, there is an evil to be remedied. Weiler's view may be taken as the most recent expression of this sometimes tacit and sometimes explicit assumption. Needless to say, the particular picture of ideal labor-management relations implicit in this conception cannot be realized absent unionization, and so the strategy of extending union power and filling gaps in legal coverage seems inevitable.

The left and right critiques raise substantial questions about the theoretical adequacy of this middle view. It simply does not offer a coherent picture either of rights and values or of pragmatic goals. The radical-left and Epstein critiques together surely show that the Wagner Act system neither respects consistently the property rights of management nor has expropriated in any systematic way a determinable set of these rights to labor-either collectively or to individual workers.

I suppose the world would be well-entitled to greet a complaint of theoretical inadequacy with a yawn of indifference, if only the system had a fair prospect of future success to recommend it. Though intellectuals and theoreticians might protest, one should be willing to concede that if a system makes those caught up in it happy, and does so in a way that does not seriously encroach on

st Weiler, Promises to Keep, supra note 33, at 1795-97.

as Id. at 1781-86.

ss Id. at 1805.

s7 See Weiler, Freedom of Contract, supra note 33.

${ }^{33}$ Id.; cf. supra text accompanying note 11.

3ง Weiler, Freedom of Contract, supra note 33.

10 Id. 
either their dignity or their sense of humor, then it is unwise to cavil-unless, at least, one has something that offers a fairly secure promise of greater enjoyment at no cost in decency or humor. In fact there is a very large measure of doubt that the system is delivering prosperity and decency, and there is also a suspicion that it holds a declining promise of delivering these in the future.

It seems to me that the time has come for a review of the premises, and not just the details, of our employment-law system. We should consider afresh what goals such a system should seek to attain and what rights it must respect. In such a reconsideration we should ruthlessly beat down the temptation to treat such hoary platitudes as "industrial peace," "partnership," and "equal bargaining power" as though they were satisfactory analyses of or dispositive answers to any question.

One question in particular I would like to raise is whether it is any longer necessary or even wise to retain the premise that the best protection of workers' interests is to be found in a restructured market, that is, one in which workers are assured of their rights by guaranteed access to a process of bargaining and in which their strength is assured through the monopolistic principle of exclusive representation. ${ }^{41}$ Is it so clear that such a restructured system is superior to the market that obtains for the purchase and sale of other vital necessities, for example, shelter, consumer goods, and transportation? Those markets certainly are not organized by granting monopoly status to certain actors and then sanctifying the results of their dealings. On the contrary, monopolies are forbidden and penalized, and where, because of market failure or for distributional or paternalistic reasons, the results of free bargaining are thought intolerable, government intervention is direct: examples include public housing, food stamps, nonwaivable implied warranties, even administered prices. Is it so clear that analogous interventions would offer fewer benefits to labor than a government-sanctioned monopoly? Maybe Congress was unready for them in the 1930's, but looking at the matter afresh today, is it so clear that direct government interventions pose a greater threat either to efficiency or to liberty?

The moral issues that seem to me to be implicated in this domain have to do, first of all, with the rights of individual actors to control their persons and the product of their work and thus with

\footnotetext{
4 For one of the most compelling recent accounts of the conventional view, see Note, Collective Bargaining as an Industrial System: An Argument Against Judicial Revision of Section 8(a)(2) of the National Labor Relations Act, 96 HARv. L. REv. 1662 (1983).
} 
their right to acquire and manage property, as well as with their right to supply or withhold their labor. At the same level of generality, and of no less importance, is the right of each member of the community to a fair share of scarce resources, or to a decent minimum of resources necessary for that individual's sustenance, development, and flourishing. ${ }^{42}$

A different sort of value question concerns our conception of the satisfactions derived from work. Most of us spend a significant portion of our lives in some form of employment, yet for some of us a sense of control over our work product and working conditions forms a much greater share of job satisfaction than for others. The extent to which labor law should restructure free-market bargaining ought to be related to the importance we attach to the exercise of such control. The Wagner Act system puts great weight on the processes of participation and bargaining. Another sort of laborlaw system might place primary emphasis on setting minimally acceptable wage levels and working conditions by direct government intervention, if the wages or conditions themselves, and not the ability to have a certain structured form of input, were the main thing that workers valued.

A cross-cutting concern is the scope of political intervention-the extent to which the organized collectivity should be empowered to develop its own vision of an ideal organization and should be entitled to intervene in individual choices to implement that vision.

I shall now turn to a discussion of the goals and rights a laborlaw system might want to serve and to an analysis of the ways in which the Wagner Act system in fact serves or fails to serve them. Finally, I shall contrast the Wagner Act system of collective bargaining with a system of free individual choice supplemented by minimally acceptable statutory terms to remedy perceived failures of a free labor market to deliver the goals and rights we seek.

\section{GoALS AND RIGHTS}

From the congeries of goals that an employment-law system might seek to serve and of the rights it might recognize, the principal ones that I would identify are freedom of association; the provision of a social minimum of resources; the redistribution of proprietary rights in the products of labor; job security; freedom from harrassing, demeaning, and arbitrary treatment; industrial democ-

42 See Fried, supra note 26 , at $100-03$. 
racy; efficiency; and industrial peace. I will discuss these briefly.

To the extent that workers share a commonality of interest, sympathy, and inclination, there would seem to be a significant value in recognizing their right to join together for mutual support and assistance. Indeed it is one of the offenses of the earlier era in labor law that such association was often viewed not benignly but as a potentially criminal combination. ${ }^{43}$

A decent society assures its members at least a minimum of resources to lead an acceptable life and to develop their own and their children's potential. Since such a provision must ultimately derive from the productive efforts of the citizenry, it is of particular concern that those who are willing and able to devote a substantial part of their energies to productive work should be able to earn at least that social minimum. A situation in which any significant portion of the working population is unable by its own efforts to earn the social minimum and either falls below it or can only enjoy the social minimum by virtue of transfer payments bespeaks a condition either of injustice (in the former case) or of excessive dependence (in the latter). This may lead to political instability, conditions fostering demagoguery, and a general undermining of the spirit of dignity and independence in the population. ${ }^{44}$

It is frequently suggested that one goal of an employment-law regime is to procure a greater share of the benefits of an enterprise for the workers. Various approaches to this goal have been taken. Some see it as a strategic opportunity to pursue greater income equality within the population as a whole..$^{45}$ Others, taking as their point of departure what I would suppose to be some form of the Marxist conception of exploitation, are more concerned with a redistribution of the joint product of labor and capital. ${ }^{46}$ This form of redistribution is not directed at accomplishing a fair division of income within the society as a whole, but rather might be taken as a recognition of rights in the productive process itself. It is as if one were arguing that working people have a natural (that is, pre-

4s See, e.g., Bedford Cut Stone Co. v. Journeymen Stone Cutters' Ass'n, 274 U.S. 37, 54 (1927); Loewe v. Lawlor, 208 U.S. 274, 292-97 (1908).

14 See Fried, supra note 26, at 102.

4 See, e.g., NLRA § 1, 29 U.S.C. $\$ 151$ (1982) (a purpose of the NLRA is to prevent depression of wage rates and erosion of wage earners' purchasing power); Klare, Deradicalization, supra note 1, at 290 (Wagner Act may have led people to contemplate a "radical restructuring of relationships within the workplace").

4s See, e.g., Harry Braverman, Labor and Monopoly Capital 377 (1974). Of course, a thoroughgoing Marxism recognizes no justified attribution of value to capital as such, and thus it recognizes no claim to industrial product based on the ownership of the means of production. 
conventional) right to some larger proportion of the joint product that they help to produce than the conventional legal system recognizes. The changes in the legal system would then represent a recognition of these rights. This view is one with which Epstein might have particular difficulty dealing, since it cuts beneath the level at which his analysis begins. ${ }^{47}$ We shall see below the extent to which the Wagner Act system does indeed represent an attempt at redistribution.

Quite apart from matters of income or distribution, an offense to human dignity is said to occur when some persons exercise what is thought to be a demeaning measure of control over significant portions of the lives of others. This offense is said to occur when workers are subject to arbitrary measures of discipline, discharge, promotion, allocation of tasks, working conditions, and the like. But even where the control is not exercised in an arbitrary way, the offense is thought to exist where the worker has little opportunity to participate in the processes that determine the rules that govern his activities, whether in the formulation of general industrial policy or in the design and execution of the particular tasks that the worker performs.

It has been suggested more than once that our system of labor law must and does serve the concerns of efficiency and productivity. There are statistics purporting to show that union labor is more productive than nonunion labor..$^{48}$ In any event, a regulatory scheme granting substantial recognition to union power, such as the Wagner Act system, may at some periods have promoted industrial peace and thus in turn may have avoided the deadweight loss of strikes, lockouts, and other forms of industrial disruption. ${ }^{40}$

Two rather different approaches to efficiency are addressed by these suggestions. One suggests that empowered labor unions are better able to aggregate and deliver a service to management than an unorganized work force. The union thus appears as a firm, internalizing organizational efficiencies and passing some of them on to its customers while sharing the remainder of the benefits with its members. ${ }^{30}$ The other approach speaks of industrial peace: re-

47 See supra text accompanying notes 26-29.

48 See R. Freeman \& J. Medopr, What Do Unrons Do? 162-80 (1984) (citing especially the experience in the bituminous coal industry). But see Posner, Some Economics of Labor Law, 51 U. CHI. L. Rev. 988, 1000-01 (1984).

49 See NLRB v. Jones \& Laughlin Steel Corp, 301 U.S. 1, 42 (1937) (experience shows that employees' right to collective bargaining is often necessary to industrial peace).

so See Oltuer E. Whliamson, Markets and Hirrarchies 73-78 (1975); Freeman \& Medoff, Two Faces of Unionism, 57 PuB. INTEREST 69, 76-82 (1979). 
ducing strikes and the like. This industrial peace argument suggests that unions and unionization offer benefits to workers that employers are unwilling to offer directly and that in return for the right to unionize, the work force will agree to minimize its disruptions of the work place. To be sure, some employers do provide these benefits, or their sufficient equivalents, and such employers often avoid unionization. ${ }^{\text {s1 }}$

On the other hand, there is a kind of efficiency-let us call it "overall productivity" - that a national labor-law system may impede by decreasing competition among employers and employees. Unionization might cause decreased productivity, and if unionization is carried out pursuant to a federal statutory scheme that affects all firms equally, there would be little competitive pressure toward more efficient production. Moreover, if consumers were blocked by protectionist measures from seeking cheaper end products manufactured abroad, what we would have is, at best, a redistribution from consumers to employers and employees and, at worst, a deadweight loss that is insulated from the competitive pressure that should squeeze it out.

\section{Goals and Rights in the Wagner Act System}

With these general goals and rights of labor law in mind, I shall now examine their place in the Wagner Act system.

\section{A. Freedom of Association and Union Empowerment}

Sections 7, 8, and 9 of the NLRA ${ }^{52}$ speak in the language of free association. The phrases of the Act as well as the familiar supporting rhetoric seem to be addressed to the offenses of the old regime, in which deputy sheriffs, Pinkertons, judges with their injunctions, and just plain goons denied the associational freedom of working people. But note that the Act goes a great deal further than a concern for freedom of association alone would suggest. For the Act not only protects the voluntary associations of workers but serves to empower them.

This empowerment protects the workers' right to associate by abridging the employer's right not to associate with union members. Under the Wagner Act system, employers are no longer free to refuse to hire union members or to require employees not to join

61 See R. Frgeman \& J. Mgdorf, supra note 48, at 150-54.

s2 29 U.S.C. $\$ \S 157,158,159$ (1982) (rights to organize, bargain collectively, and elect representatives). 
unions as a condition of employment, via so-called "yellow dog" contracts. $^{\text {.s }}$ At stake for the employer is not only his right to discriminate against union members but also the economic advantage that may result from dealing with a divided work force. Although there are surely those who harbor a personal bias against union members (as others are bigoted towards Jews or Catholics), the real reason why many employers wish to keep unions out is that unionization may improve the employees' bargaining position and thus their ability to compel greater concessions from the employer. Anti-union bias may thus be motivated, unlike racial and other kinds of bigotry, by rational self-interest, which the antidiscrimination aspect of the Act tends to undercut.

As a first step toward recognizing the empowerment that the Wagner Act did accomplish, consider the principle of Republic Aviation and its progeny, which requires an employer not only to tolerate union membership in his employees but also to allow union activities, including organizational activities, on his property. ${ }^{54}$ To be sure, this doctrine is a narrow one and may be seen as an instance of the nondiscrimination thesis rather than something that goes beyond it. One way to look at this doctrine, after all, is as a bar to employer discrimination against activities engaged in just because they are union-related.ss

Yet the empowerment created by the Wagner Act system goes further. More is at stake than provisions against "yellow dog" contracts and discrimination. There may be a lack of bite to such provisions where the employer is free to replace striking workers or to bind his employees to a no-strike contract. The crucial step in empowerment comes in the duty to bargain and in the exclusivity principle.

B. The Duty to Bargain with the Union as Exclusive Representative No topic in Wagner Act labor law has received more attention

ss NLRA § 8(a)(1), 29 U.S.C. § 158(a)(1) (1982).

se See Republic Aviation Corp. v. NLRB, 324 U.S. 793, 802-03 (1945) (passing out union application cards on employer's property); Eastex, Inc. v. NLRB, 437 U.S. 556, 572 (1978) (passing out union newsletters on employer's property).

${ }^{83}$ Of particular significance to the associational aspect of this obligation are the differences in the degree to which the employer is bound to accept such activities, depending on whether they are engaged in by or only addressed to his employees. Compare Republic Aviation, 324 U.S. at 802-03, with NLRB v. Babcock \& Wilcox Co., 351 U.S. 105, 113 (1956) (employer allowed to prevent union leafletting by nonemployees on company premises). This interpretation of Republic Aviation grew out of conversations with my colleague David Rosenberg. 
than the duty to bargain in good faith. ${ }^{56} \mathrm{My}$ impression is that the courts and even the most pro-union Labor Boards have more or less held the line against turning the duty to bargain in good faith into an obligation to make concessions or into a tacit authorization for judges or Board members to impose what seemed to them to be minimally reasonable contract terms. ${ }^{\text {sz }}$ The best evidence for this proposition is Paul Weiler's recent conclusion that the Labor Board should indeed be given explicit authority to impose minimally reasonable contract terms at least in what he considers egregious cases, for example, where management, after losing a tough and vicious representation campaign, adamantly refuses to grant the union the fruits of its victory by negotiating an acceptable first contract. ${ }^{88}$

How are we to understand this duty to bargain? Does it, standing all by itself, imply some measure of collective expropriation, of empowerment? I do not think so. All by itself it is but an extension of the nondiscrimination principle, for what the duty to bargain expresses is a prohibition against boycotting the union that represents the expression of the workers' associational rights. The duty to bargain in good faith, standing alone, thus might be seen as an affirmative statement of what antitrust law-the law that seeks to ensure a competitive market-states in the negative as a delict: a refusal to deal. ${ }^{5 \theta} \mathrm{We}$ have here another expression of the antidiscrimination principle: the employer may not refuse to treat with a supplier of labor just because it represents an aggregate of employees.

The duty to bargain collectively, however, does not stand alone. First, there is the rule forbidding an employer from unilaterally instituting changes in mandatory subjects of bargainingwhether the changes are favorable to employees or not-without first bargaining (if need be to impasse) with the union. ${ }^{80}$ This seems to me to be a significant step in the direction of collective expropriation. The employer is not refusing to bargain in such a

se See, e.g., Cox, The Duty to Bargain in Good Faith, 71 HARv. L. REv. 1401 (1958).

${ }^{87}$ See NLRA § 8(d), 29 U.S.C. § 158(d) (1982); NLRB v. General Elec. Co., 418 F.2d 736, 761 (2d Cir. 1969) ("[T] he Board is not to control the substantive terms of a collective bargaining contract."), cert. denied, 397 U.S. 965 (1970). But cf. NLRB v. Reed \& Prince Mfg. Co., 205 F.2d 131, 134 (1st Cir.) ("[T] he Board . . . must take some cognizance of the reasonableness of the positions taken by an employer in the course of bargaining negotiations."), cert. denied, 346 U.S. 887 (1953).

ss Weiler, Freedom of Contract, supra note 33.

so Of course, in antitrust law the refusal to deal must be concerted.

co See NLRB v. Exchange Parts Co., 375 U.S. 405, 409 (1964); NLRB v. Katz, 369 U.S. 736, 744 (1962). 
case. $\mathrm{He}$ is not boycotting the union. $\mathrm{He}$ is just acting unilaterally before or during bargaining. A unilateral act does not necessarily cast doubt on the willingness of an employer to bargain. After all, it has not been thought that a union's unilateral exercise of its prerogatives is inconsistent with the union's duty to bargain in good faith. ${ }^{61}$ I concede that an employer's unilateral action might make the union's position less favorable. Nevertheless, the ban on unilateral action by employers is a significant expression of an obligation to regard the union as having some unspecified authority in the premises and thus amounts to a partial transfer to the union of what was once an unrestricted authority. ${ }^{62}$ Just such authority is a traditional indicium of ownership, and thus I see this extension of the duty to bargain as an expropriation pro tanto.

Second, the duty to bargain is coupled with the principle of exclusive representation. ${ }^{63}$ This principle not only compels the employer to treat with no other labor organization but also forbids the employer to bargain with individual employees, both present and prospective. ${ }^{.4}$ If there is empowerment, if there is expropriation to the collectivity, this is where I would locate it. This is what needs to be explained, and no explanation solely in terms of associational rights will suffice.

\section{C. "Employer Domination"}

This train of thought should be completed by a reference to what appears to me to be a very significant feature of the Wagner Act system that will affect the development of industrial relations in the next generations. The Wagner Act does not simply protect concerted activities. In section $8(a)(2),{ }^{65}$ it specifically prohibits what is designated as "employer domination," that is, any contribution to or participation in a labor organization by an employer. To be sure, this provision has had a curious history. On one hand,

-1 See NLRB v. Insurance Agents' Int'l Union, 361 U.S. 477 (1960) (union-sponsored program of work stoppages, slowdowns, and demonstrations, carried on during negotiations between the union and management, does not constitute a violation of the union's duty to bargain in good faith).

63 Cf. NLRB v. Exchange Parts Co., 375 U.S. 405, 409-10 (1964) (benefits unilaterally conferred by company upon employees shortly before union representation election constitute unfair labor practice).

os NLRA § 9(a), 29 U.S.C. § 159(a) (1982).

ot See Emporium Capwell Co. v. Western Addition Community Org., 420 U.S. 50 (1975); J.I. Case Co. v. NLRB, 321 U.S. 332 (1944).

os NLRA § 8(a)(2), 29 U.S.C. § 158(a)(2) (1982). For a discussion of the importance of these issues in the debates surrounding the evolution of the Wagner Act, see PETER Irons, The New Deal Lawyers ch. 11 (1982). 
courts have tolerated considerable departure from the literal terms of the Wagner Act stricture, perhaps recognizing that as much as anything it arose as a particular response to what at a particular moment of history was deemed a particular evil. ${ }^{68}$ On the other hand, as the Yeshiva University case showed, ${ }^{67}$ this adversary conception of the relations between labor and management has meant the exclusion from Wagner Act coverage of whole classes of employees whose work includes supervisory or policymaking responsibilities. This stricture of section 8(a)(2) of the Wagner Act-once the particular history that may have brought it about has been put behind us-can hardly stand as a protection either of associational rights or of the nondiscrimination principle. Rather it is the expression of a flat requirement of a particular kind of association, a kind of association that in some circumstances none of the parties involved may prefer.

\section{Distribution and Dignity: Individual versus Collective Rights}

Under the Wagner Act system, unionization appears intended to assure working people a reasonable income under conditions that are safe, secure, and dignified, that is, free from arbitrary and demeaning impositions. It is by no means clear, however, whether the benefits of unionization were designed to be mandatory or only optional. To be sure, the provisions of NLRA sections 7, 8(a)(1), and $8(a)(3)^{68}$ are intended to protect unionization from employer interference. Yet there are values that workers have found to weigh against the decision to unionize. Employers conducting campaigns against unions have found that the most persuasive arguments have emphasized the payment of union dues, the subjection to union discipline and to union officers, the involvement in union politics, the possibility of being called out on strike or being required to honor a picket line, and the more formal and adversarial nature of labor-management relations that unionization is thought to produce. ${ }^{69}$ All together one might refer to these worker concerns as a resistance to forced collectivization. Once a union has been certified or has established a majority status, then, by the J.I. Case

\footnotetext{
4 See Jackson, An Alternative to Unionization and the Wholly Unorganized Shop, 28 SYRAcUSE L. REv. 809, 822-23 (1977); Note, supra note 41, at 1663-68, 1674.

${ }^{67}$ NLRB v. Yeshiva Univ., 444 U.S. 672 (1980); cf. Klare, The Bitter and the Sweet: Reflections on the Supreme Court's Yeshiva Decision, 71 Socialist Rev. 99, 105 (1983) (the "repressive outcome" of Yeshiva is "fully consistent with moderate, integrative industrial relations thinking").

as 29 U.S.C. $\$ \$ 157,158(\mathrm{a})(1), 158(\mathrm{a})(3)$ (1982).

- See J. Lawson, How to MBet the Challenge of the Union Organizer § 6 (1968).
} 
exclusive-representation principle, ${ }^{70}$ a worker no longer has any option but to be represented by the union. Even though he may not be compelled to join-even though he need do no more than pay an agency fee-he will still be bound by the result of union bargaining, and unless he does join the union (thereby rendering himself susceptible to union discipline ${ }^{71}$ ) he will not even have a democratic voice in union affairs.

Thus individual workers pay, and feel themselves to pay, a significant price for the distributive and dignitary gains that the union might procure for them. If such gains are really a matter of right, then it seems odd that the individual worker must bear the costs of unionization in order to enjoy them. Why, if a worker has a right to safe, secure, and dignified working conditions, should his ability to enjoy that right depend on his willingness to organize collectively?

We have indeed moved toward a system that recognizes individual workers' rights independent of labor-union bargaining. How else can we understand FLSA, ${ }^{72}$ OSHA, ${ }^{73}$ ERISA, ${ }^{74}$ and the recent development of the doctrine requiring good faith in terminating employees at will? ${ }^{75}$ As a matter of political philosophy, we observe a tension between the recognition of individual and of collective rights. The J.I. Case vision is a vision of collective empowerment, or of the creation of a right in a collectivity, in which individuals participate only as they participate in that collectivity, and on its terms. By contrast, Title VII, ${ }^{76}$ the good-faith discharge doctrine, and the FLSA all create individual rights, ${ }^{77}$ and if there is an expropriation here, or a limitation of proprietary control, it is an expropriation to individuals.

This contrast between individual and collective rights, individual and collective empowerment, may be connected to the history of the Wagner Act. Unionism has historically been associated with a strong collectivist strain-a tendency that goes well beyond stra-

${ }^{70}$ See J.I. Case Co. v. NLRB, 321 U.S. 332, 337-39 (1944).

${ }^{71}$ See NLRB v. Allis-Chalmers Mfg. Co., 388 U.S. 175, 178-95 (1967); Machinists Local 1327 v. NLRB, 725 F.2d 1212, 1217 (9th Cir. 1984).

72 Fair Labor Standards Act, 29 U.S.C. $\$ \S 201-219$ (1982).

${ }^{73}$ Occupational Safety and Health Act, 29 U.S.C. \$§ 651-667 (1982).

74 Employee Retirement Income Security Act, 29 U.S.C. §§ 1001-1453 (1982).

75 See generally Mary Ann Glendon, The New Family and the New Property 158-70 (1981).

${ }^{73}$ Civil Rights Act of 1964, tit. VII, 42 U.S.C. $\$ \S 2000 \mathrm{e}$ to $2000 \mathrm{e}-17$ (1982).

77 See, e.g., Alezander v. Gardner-Denver Co., 415 U.S. 36, 48-49 (1974) (Title VII offers a procedure for the protection of individual rights that "supplement[s], rather than supplant[s], existing laws and institutions relating to employment discrimination."). 
tegic or instrumental concerns. Thus it is not surprising to find a strong collectivist direction in the major empowering legislation of the American trade union movement, legislation that is championed by persons strongly affected by the trade-union spirit. ${ }^{78}$ But there is a great deal more to this story. The Wagner Act came at a time when the New Deal was flirting with collectivist solutions to economic problems across the board and may be seen as the labor complement to the NIRA ${ }^{79}$ scheme of government-sponsored and government-sheltered cartels throughout the economy. ${ }^{80}$ Though the management side of this experiment in corporativist organization was abandoned, it is not farfetched to see the Wagner Act-with its collectivist approach to empowerment and rights-as the principal surviving feature of that experiment. The peculiar history and traditions of the union movement come in to explain why the experiment has survived there, and there alone.

\section{E. Income Fairness}

The measure of income redistribution accomplished by unionization under the Wagner Act is by no means uniform. Overall there seems to be little doubt that there is a significant unionization "premium" to organized workers. ${ }^{81}$ But it is difficult to char-

${ }^{28}$ Nor is it surprising that when the NLRA was amended in 1947 by the Labor Management Relations (Taft-Hartley) Act, Pub. L. No. 80-101, 61 Stat. 136 (codified in scattered sections of 29 U.S.C. (1982)), the amendments had as their dominant theme not just a pro-management but a pro-individual bias. For example, section 101 of the Taft-Hartley Act amended section 7 of the NLRA by adding the right of an employee to refrain from union activities (current version at 29 U.S.C. $\$ 157$ (1982)). Section 101 also amended section 8 of the NLRA to provide that an employer may not discriminate against an employee for nonmembership in a union (current version at 29 U.S.C. $\$ 158(\mathrm{a})(3)$ (1982)), and to provide that unions may not coerce self-employed persons to become members by refusing to handle their products (current version at 29 U.S.C. $\$ 158(b)(4)(i)(1982)$ ). The same is true, of course, of Title I of the Labor-Management Reporting and Disclosure Act of 1959, 29 U.S.C. $\S 411$ (1982) (bill of rights for members of labor organizations).

70 National Industrial Recovery Act of 1933, Pub. L. No. 73-10, 48 Stat. 31 (terminated by Exec. Orders Nos. 7252 (Dec. 21, 1935) and 7323 (March 26, 1936)). See A.L.A. Schechter Poultry Corp. v. United States, 295 U.S. 425 (1935) (declaring operative portions of NIRA unconstitutional).

so The Bituminous Coal Conservation (Guffey Coal) Act of 1935, Pub. L. No. 74-824, 49 Stat. 991 (repealed 1937), was a particularly blatant example of union-management corporativism in an industry given to union-management actions to stifle competition in the "market." On the nature of the industry, see United Mine Workers v. Pennington, 381 U.S. 657 (1965) (UMW and large coal companies accused of conspiring to drive smaller companies out of business). For a description of the labor provisions of the Guffey Coal Act, see Carter v. Carter Coal Co., 298 U.S. 238, 283-84 (1936). See also P. IRoNs, supra note 65, at 248-51.

- See R. Frreman \& J. Medorf, supra note 48, at 43-54; Daniel Mrtchell, Untons, WAGES, AND INFLATION 77-85 (1980). 
acterize this premium in any sense as a device leading to general equality of income. The unionization premium for airline pilots is high, though a rather small premium obtains for hospital and other service workers. ${ }^{32}$ In fact, the unionization premium seems to reflect notions of wage equity less than it does the realities of the marketplace. And those realities, in turn, reflect not just the economic strength of the union of workers, or even the market value of scarce worker skills, but often the ability of management to pass along labor costs to consumers. This ability could explain the historically high level of wages in a (formerly) regulated industry like air transport or in industries like steel and automobiles, long sheltered from competition by protective tariffs and oligopoly. It also may explain the deflation of those wage rates with the removal of government support for noncompetitive price structures or the advent of foreign competition.

The loss of this unionization premium by airline pilots upon deregulation is unlikely to cause the shedding of many tears. The case of auto and steel workers is more complicated. What is the role of the unions in the deterioration of earnings from a level (including fringes) of some forty thousand dollars per year to twentyfive thousand? At this point we are indeed talking about significant aspects of the profile of the distribution of wealth within the society. If one is inclined-as I am-to view it as one of the glorious characteristics of American society that such a large proportion of its members belong to what might be called "the middle class," the role of some unions in procuring this result is surely significant. Nevertheless, this distributive benefit of unionization seems unsystematic in its coverage, and I suspect that it tends to be connected disproportionately to inefficient and therefore declining industries. In the automobile and steel industries, the general distribution of wages might well have been driven by a cozy arrangement between labor and incompetent management, sheltered for many years by the absence of effective foreign competition.

It may be incorrect, therefore, to assume that unionization is either necessary to or adequate for the maintenance of middleclass incomes in efficient, unregulated, and competitive industries. Viewed principally as a system for obtaining fair wages for workers, the labor movement may be less crucial in today's economic

${ }^{82}$ Flax, Pay Cuts Start before the Job Even Starts, ForTuNe, Jan. 9, 1984, at 75-76 (airline pilots); Miller, Becker \& Bruisky, Union Effects on Hospital Administration, 28 LAB. L.J. 512, 516 (1977); Weiler, Freedom of Contract, supra note 33 (collecting references to studies on wage differentials in various industries). 
climate than it was during the New Deal.

\section{F. Industrial Democracy: Dignity}

In one sense the American union movement has been a clear success: it has provided workers with a measure of security against arbitrary impositions by management, usually in the person of foremen and other supervisory personnel who are incompetent or have their own axes to grind. The value of this gain cannot be overstated. What can be overstated is the extent to which unionization and the Wagner Act system are necessary to procure this result today. The fact is that numerous progressive employers have elaborate personnel schemes that provide protections and benefits analogous to those offered in unionized settings. To be sure, in many cases-but not all-such benefits are offered because they are the most effective way to discourage unionization. Arbitrariness by low-level petty tyrants is not, after all, in the interests of the owners or the enterprise as a whole. But it would be a mistake to confuse the history of this situation with its necessary future. It seems to me far from clear that all features of the Wagner Act system are necessary today to create the incentive for management to offer such schemes. Where such protections are seen as the normal, decent way of doing business, one might expect workers to demand such protections in individualized, semi-individualized, or collective bargaining. Further, one might expect society-through the courts and legislatures-to insist on such terms of protection as another aspect of the decent social minimum. ${ }^{83}$

The price that is paid by reliance on the Wagner Act system to procure these organizational benefits is a necessarily rigid and adversarial relation between workers and management, a gap in coverage for so-called "managerial" employees, ${ }^{84}$ and, more important, a limitation on developing possibilities for worker involvement in the enterprise. Indeed, the tendency toward rigid segmentation of work between task-defining and task-executing functions may be attributable in part to the Wagner Act system. Further, the Wagner Act system, through section 8(a)(2), poses an obstacle to worker-owned enterprises, as well as to other schemes of worker participation. ${ }^{85}$ The kinds of employee involvement that make

as. Fried, supra note 26, pt. I.

See supra note 67 and accompanying text.

ss See generally Note, Worker Ownership and Section 8(a)(2) of the National Labor Relations Act, 91 YALE L.J. 615 (1982). 
some aspects of the high-tech industry so exciting and productive ${ }^{86}$ are readily available under the Wagner Act system only to "managerial" employees. When applied to those who are susceptible to unionization, they might constitute "company domination" or could only be instituted under a collective-bargaining agreement with a union, even though neither management nor the employees may desire a union.

This last feature, as well as the inconsistent ability of collective bargaining to procure an acceptable social minimum, might be viewed as an example of the Wagner Act system's bias-rather than its alleged neutrality-toward unionization as the desirable framework of worker-management relations, that is, as a good thing regardless of the ability of unionization to produce benefits for individual workers.

\section{G. Efficiency and the Reconstructed Market}

Unions aggregate suppliers of labor and may be able to procure efficiencies analogous to those captured by capital through the creation of firms. The collective expropriation to, and empowerment of, unions fostered by the Wagner Act system might be thought to advance this aggregational efficiency in two different ways. First, the Wagner Act system protects union "firms" from the problem of free riders by enabling unions to capture external benefits that free riders might carry away. Second, this system "corrects" the market for labor by removing what is thought to be an inherent, "unfair," or structural imperfection in that market: the peculiar vulnerability of individual suppliers of labor, who do not enjoy unique capabilities and thus are unable to demand rent for those capabilities they do have. This last argument is a classic one. ${ }^{87}$ It is, after all, a version of the argument that Marxists rely on, but it has appeared in Supreme Court opinions as well:

[Labor unions] were organized out of the necessities of the situation. A single employee was helpless in dealing with an employer. He was dependent ordinarily on his daily wage for the maintenance of himself and family. If the employer refused to pay him the wages that he thought fair, he was nevertheless

${ }^{86}$ Cf. Tracy Kidder, The Soul of a New Machine 272-76 (1981) (illustrating the role of employee involvement in making decisions about working conditions as a substitute for financial incentives).

${ }^{87}$ See Arthur Okun, Prices and Quantities: A Macroeconomic Analysis 122-23; see generally id. chs. 2-3 (1981). 
unable to leave the employ and to resist arbitrary and unfair treatment. Union was essential to give laborers opportunity to deal on equality with their employer. ${ }^{88}$

Both arguments for the efficiency of the Wagner Act system have been weakened by economic and social developments over the last fifty years.

1. Free Riders. An important argument for the monopoly status granted to unions under the Wagner Act system is that it prevents some workers from free riding on the efforts and sacrifices of others, with consequent unraveling of the union "firm." This claim should not be accepted uncritically. First, both the unions' monopoly and their ability to exclude free riders have ceased to be complete. Second, if there is any substance to the argument that union "firms" offer significant efficiency gains to employers, free riders should not be able fatally to undermine the union's role.

The principal monopoly power of a union comes from its position as exclusive representative of a work force. The employer may not negotiate with other prospective suppliers of labor. This is implicit in the employer's duty to bargain exclusively with the union and in the prohibition on unilateral changes (even changes benefiting the workers) during both organization and bargaining. ${ }^{89}$ Nevertheless, the monopoly is only partial. Under Mackay Radio, employers can hire permanent replacements in the event of a strike, ${ }^{90}$ though they may not bargain with such replacements. ${ }^{91}$

Nor is the union's ability to exclude free riders complete. The free-rider problem arises from the union's obligation, under its duty of fair representation, ${ }^{92}$ to represent all members of a bargaining unit, whether they are members of the union or not. Whatever benefits the union is able to win for its members must go to nonmembers in the same bargaining unit as well.

The existence of free riders tends to weaken the union's monopoly. Mancur Olson's classic analysis shows how holdouts tend to cause cartels to break down in the direction of free competi-

\footnotetext{
Bs American Steel Foundries v. Tri-City Cent. Trades Council, 257 U.S. 184, 209 (1921) (Taft, C.J.).

80 See supra note 60 and accompanying text.

- NLRB v. Mackay Radio \& Tel. Co., 304 U.S. 333, 345-46 (1938).

-1 Cf. NLRB v. Erie Resistor Corp., 373 U.S. 221, 230-32 (1963) (employer may not offer superseniority rights to strike replacements and employees breaking the strike to return to the job).

"see Vaca v. Sipes, 386 U.S. 171, 182 (1967) (duty of fair representation a "bulwark" to protect nonunion employees from arbitrary union conduct).
} 
tion..$^{93}$ Free riders, by preventing the group from completely capturing a benefit, tend to weaken the incentive to act collectively. ${ }^{94}$

There are, however, two sources of the benefits thought to be attributable to unionization: monopoly rents (the extent to which the union wage exceeds a competitive-market wage) and the efficiencies resulting from the union's position as a supplier of aggregated labor. ${ }^{95}$ Free riders may exert pressure in the direction of a competitive wage, but it is unlikely that they would be able to undermine efficiency gains that are of benefit to both workers and management, such as the savings produced by formalized grievance procedures. The union may not exclude free riders from its grievance procedures, ${ }^{96}$ and a worker who chose to ignore them would probably be seen by management as a troublemaker, not as a potential wedge for driving the union out.

The real question is why we do not treat suppliers of labor like other firms. Why must unions have a monopoly? If unions do in fact increase productivity-and perhaps sometimes they $\mathrm{do}^{97}$-then unions as suppliers of labor should have a competitive advantage, at least where such an increase equals or exceeds the cost of above-market union wages. A possible response to this assertion is that labor is inherently weak and needs the protection of a government monopoly.

2. Supposed Special Characteristics and Vulnerabilities of Labor. There is a notion that workers cannot hold out for better deals because they must work in order to feed their families, while management can hold out or seek alternative investments. Therefore management has labor over a barrel. This was the burden of Chief Justice Taft's dictum in the American Steel Foundries case. $^{98}$ But the union as a supplier of labor might sustain workers out of its own resources during bargaining, if it truly is able to capture a better deal for them and to offer management a better deal. Why, after all, is not a union like any other service firm that has no fixed capital and only aggregates, organizes, and markets the services of others? And why exactly do we care about equalizing the bargaining power of labor and management?

23 Mancur Olson, The Logic of Collective Action 40-42 (1965).

or See id. at 41.

9s See supra note 50 and accompanying text.

- See supra note 92 and accompanying text.

97 See R. Freeman \& J. Medorp, supra note 48, at 162-80; Steven Allen, Unionization and Productivity in Opfice Bumding and School Construction 4-7 (National Bureau of Economic Research Working Paper No. 1139, 1983).

28 See supra note 88 and accompanying text. 
Is it because workers are always so weak that they will be exploited? This is certainly not inevitably the case. Consider some obvious examples: where workers have relatively unique skillsstar baseball players, high-level executives-there is no need to protect them. Were high-advantage employees to organize, they might extract even greater advantages for themselves. ${ }^{99}$ Consider a union of concert soloists or star baseball players. The bargaining power of the star would be diluted by a requirement that players of lower skill would have to be included in the bargaining unit, and this would bring down the average demandable wage. Indeed the obvious disincentive to better players to form a union with weaker ones (and the unavailability of the device of forming separate bargaining units of superior and average players) has led to a departure from the usual trade-union model in the case of athletes, actors, and musicians: the unions establish a minimum standard of compensation, with stars individually negotiating for still higher rates. ${ }^{100}$

Thus it seems that unionization tends to protect those who have low individual bargaining power. There is a bias toward the less advantaged: if they can get the job, they are in the union, or at least must be represented by it. But why are weak workers the objects of special concern? Consider the case of poor consumers or poor renters or poor travelers: the law does not protect them at all, or if it does, it is not by encouraging tenants' unions or consumers' unions, though these things exist. Why not?

One answer might be that workers' unions have a unique history of solidarity. But the social scientist is not going to be satisfied with this explanation, for he will want to know why workers' unions alone have had this history. Is it a combination of special vulnerability with special need? This is inadequate. A stronger thesis might be based on the special aptness of worker solidarity. Workers tend to have similar interests, and those interests tend to dominate their differences. By contrast, consumers of particular commodities-for example, milk-may tend to be quite heterogeneous in their interests, with no overriding built-in mechanism to bind them together. The very circumstances of the workplace are likely to create the occasions for feelings of sympathy and solidarity. The commonality of workers' interests will be palpable. When

\footnotetext{
ov Workers placed in the managerial category do not enjoy the protections of the NLRA, but unions of managers are not per se illegal.

${ }^{100}$ This is illustrated by the Actors' Equity system for stage performers described in H.A. Artists \& Assocs. v. Actors' Equity Ass'n, 451 U.S. 704, 706-07 (1981).
} 
this has not obtained, there have not been strong unions. For instance, where distinctions of skill have created different interests and sympathies there has been a problem: either several unions or no union at all arose. ${ }^{101}$ Also, where racial differences were seen to be of paramount importance, the conditions hospitable to a union generally never arose. ${ }^{102}$ Outside the labor area the law has not dealt with such cases of systematic weakness by fostering unwanted combinations. Rather it has gone in for direct control-either through general regulation or by setting minimally acceptable terms of conduct. Examples are price controls, as in public utilities, required terms, as in insurance regulation, and mandatory disclosure or discretionary administrative controls, as in securities regulation.

As for the supposed defenselessness of workers, their exposure and necessitous circumstances, consider the analogy to tenants and other consumers, who, with respect to necessities of food, medicine, and shelter are also in an exposed situation. The legal response there has been quite different, certainly not in the direction of compulsory tenants' or consumers' unions. It is thought that the market quite satisfactorily provides such necessities as milk, bread, and other staples because there is a large number of suppliers. Where there are many suppliers of job opportunities (i.e., employers), the same should be true, and a worker's situation would make him no more liable to any one supplier of employment than would a person's urgent need for bread make him unduly dependent on any one grocery store. Moreover, where there has been a market deficiency in these respects, the law has stepped in to mandate specific minimal terms concerning product safety, warranties of habitability, and the like. Similarly, the law has imposed specific minimal terms in the areas of unemployment insurance ${ }^{103}$ (which, after all, increases the workers' ability to hold out for a fair wage), the Fair Labor Standards Act legislation ${ }^{104}$ (which is a kind of price control, preventing workers from selling their work too cheaply), regulation of the safety of the workplace, ${ }^{105}$ employment

101 H. Mulis \& R. Montgomery, Organized Labor 13-15, 202 (1945).

${ }^{102}$ W.E.B. DuBois, Black Reconstruction in America 353 (2d ed. 1962); 1 Herbert Hinl, Black Labor and the American Legal System: Race, Work, and the Law 16-25 (1977); Klare, The Quest for Industrial Democracy and the Struggle Against Racism: Perspectives from Labor Law and Civil Rights Law, 61 OR. L. REv. 157, 158, 186 (1982).

${ }_{103}$ See, e.g., Federal-State Extended Unemployment Compensation Act of 1970, Pub. L. No. 91-373, 84 Stat. 708 (1970), noted in 26 U.S.C. $\$ 3304$ (1982).

${ }^{104}$ Fair Labor Standards Act, 29 U.S.C. \$§ 201-219 (1982).

${ }^{105}$ Occupational Safety and Health Act, 29 U.S.C. $\$ \S 651-678$ (1982). 
discrimination laws, ${ }^{106}$ and the development of the common law requirement of good faith in terminating at-will employees. ${ }^{107}$ All of these constitute ad hoc substantive interventions to remedy what arguably may be structural or moral defects in the market.

\section{Prospects}

A fresh look at the Wagner Act system suggests that much of the law must be seen as a response to the industrial problems of fifty years ago. Today's problems for labor may come from quite different directions. For instance, the goal of protecting wages from competitive pressures through unionization ${ }^{108}$ seems far less adequate now that a large percentage of all domestic manufacturing is exposed to foreign competition, that is to say, to competition with labor regimes that are not included within the same labor cartel.

More fundamentally, the whole structure of the Wagner Act system depends on the dichotomy between managers and workers, between those who exercise judgment and discretion and are identified with the long-term overall goals of the enterprise on the one hand, and those who supply labor as a relatively fungible commodity, whose work is more routine and whose horizons are more limited, on the other. ${ }^{108}$ This dichotomy makes less sense today than it once did. There may have been a time when such categorization seemed necessary to discipline large masses of low-skilled, uneducated, and politically and socially powerless workers. ${ }^{110}$ Today, however, the distinction between workers and managers has begun to wear quite thin. Many nonmanagement employees exercise considerable discretion as to the hours they work and the details and coordination of their tasks. Many of those who are designated "managers," especially in large, bureaucratic organizations, are concerned with routine tasks, involving little flexibility or discretion. Indeed, even the color of the collar hardly serves any longer as a reliable distinguishing characteristic.

Managers have traditionally worked under a large variety of contractual arrangements, varying from contracts terminable at will to contracts with fixed terms and significant protections

${ }^{100}$ Civil Rights Act of 1964, tit. VII, 42 U.S.C. $\$ \S 2000$ e to $2000 \mathrm{e}-17$ (1982).

107 See M. GLENDON, supra note 75, at 158-70.

108 See Thomas Kochan, Collective Bargaining and Industrial Relations 50 (1980) (discussing importance of unionizing all possible alternatives to union laborers in order to protect wages from competitive pressures).

${ }^{109}$ See Klare, supra note 67, at 115.

110 See Patrick Attyah, The Rise and Fatl of Fregdom or Contract 272-76 (1979). 
against early termination. They have also grouped and coordinated their efforts in every conceivable configuration, from the highly individualistic, to the informally collegial, to the carefully structured consensus-committee model, to the rigidly hierarchical. In this developing state of the industrial scene, there seems to be no good reason why a committee that includes production employees and specialists in personnel and product planning and that meets to discuss production schedules and routines should be treated differently from one made up of various financial specialists meeting to discuss plans to structure and market the company's long-term debt instruments. Nor is there any clear justification for allowing the former committee to exist only if approved under a collectivebargaining agreement with a union that is the sole permissible representative of some, but not all, of the potential members of that committee.

Reconceptualizing the worker/management dichotomy would have the salutary effect of forcing into greater prominence the distinction between owners on the one hand and workers and managers on the other. The importance of understanding and justifying the distinct functions and prerogatives of ownership vis-à-vis all employee groups, including managers, ${ }^{111}$ may have been obscured by the sharper social stratifications of an earlier day, according to which owners and managers looked much more like each other, and both looked much less like workers, than is the case today. Such an inquiry would take us back to the questions raised but never settled by Berle and Means, ${ }^{112}$ at least for those employers that are large bureaucracies and whose owners do not (as some continue to $\mathrm{do}^{113}$ ) exercise significant managerial control. More surprisingly, perhaps, such a reconceptualization might suggest new forms of industrial organization in which more of those who today are workers and managers would assume ownership responsibilities and risks. Productive processes organized today in rigid

112 See generally Friedrich HayeK, The Constitution of LiberTy 118-24 (1960) (contending that it is in the best interest of the employed-the majority-that there be a minority group of "independents" who "accept the risk and responsibility of organizing the use of resources"); 0 . Wriliamson, supra note 50, at 71-78 (discussing the efficiency of the "authority relation" and the connection between authority and the bargaining group of workers).

112 See A. Brrle \& G. Means, The Modern Corporation and Private Property 34551 (1932); see also Corporations and Private Property, 26 J.L. \& EcoN. 235 (1983) (conference articles discussing the Berle and Means analysis of the separation of ownership and control in publicly held corporations).

113 See William McEachern, Managerial Control and Performance 71-72, 124 (1975). 
hierarchical patterns might be restructured into contractually interdependent, flexible units of disaggregated suppliers. ${ }^{114}$

There are intriguing and perhaps intractable problems to be faced in any such structural realignment. I hope they will occupy me in the years to come. I shall mention three that seem to me particularly difficult. First, if we were to abandon the J.I. Case principle forbidding individual bargaining or bargaining with minority groups where there is a majority "labor organization,"11 would we want to allow a variety of deals with varying terms applicable to employees working side by side at the same job? The prospect seems strange until we recall that similar situations obtain where workers represented by different craft unions work side by side and that unions themselves have recently been negotiating less favorable deals for new entrants into declining industries in order to preserve the jobs of more senior employees. ${ }^{118}$ Moreover, European unions have always functioned without the assurance of exclusive status. ${ }^{112}$ Second, what would become of the union's bargaining leverage and its ability to call a strike under such a regime? Would that regime contemplate coalitions among the several representatives? If so, what exactly would have been accomplished by such a regime, and would not employers themselves pine for a simpler set of choices? Finally, if employers were indeed allowed to form employer-employee committees ad lib to deal with the whole range of work-related issues, might this not quite rapidly develop into a regime that is oppressive to those with the least bargaining power? After all, if such committees became the mechanism by which work assignments and other decisions were made in a particular workplace, it is hard to see how an individual employee could abstain from participating in such an important aspect of the job. To be sure, if the principle of free association were rigorously enforced-as I believe it should be-then dissatisfied employees might, without fear of retaliation, form their own organizations (unions) as well, and these organizations might then replace, or force a modification of, the system found offensive.

\footnotetext{
11 See generally Chardes Saber, Work and Politics 194-231 (1982) (American producers of standard goods might respond to low-wage foreign competitors by switching to the manufacture of specialty products in smaller, discretionary work groups that can rapidly change to new products if the need arises).

116 See supra note 70 and accompanying text.

11 Flax, supra note 82, at 75-76.

${ }_{117}$ Bok, Reflections on the Distinctive Character of American Labor Laws, 84 HARv. L. RBv. 1394, 1408, 1427-30 (1971).
} 


\section{Conclusion}

The Wagner Act system is ponderous and increasingly out of touch with national and international social, political, and economic developments. Employment law has been moving toward direct imposition of specific minimal terms and standards where problems in the workplace have been perceived. I believe that in conjunction with this trend we ought to move further in the direction of freedom for individual working men and women to choose how and with whom they will expend their productive energies. On the whole this promises greater flexibility, more mutually advantageous benefits, and more comprehensive assurance of those things that are felt to be truly indispensable to all workers. Finally, a regime that moved away from governmentally sheltered monopoly status for labor unions might provide the occasion for the revitalization of these organizations, as they compete in a more flexible way for worker loyalties and broaden the range of services they offer and the kinds of appeals they make. 